УДК 069.44:7.025.13

https://doi.org/10.24852/2587-6112.2021.6.242.253

\title{
АКТИВНАЯ КОРРОЗИЯ МУЗЕЙНЫХ ПРЕДМЕТОВ ИЗ МЕТАЛЛА И МЕТОДЫ ЕЕ ДИАГНОСТИРОВАНИЯ
}

\author{
(C) 2021 г. С.Г. Буршнева, О.Ю. Сенаторова
}

Термин «активная коррозия» широко используется для характеристики состояния сохранности археологических предметов из металла, однако до сих пор не появилось четкого определения этого понятия ни в отечественной, ни в зарубежной литературе. Авторы статьи предлагают свое определение активной коррозии музейных предметов из металла, описывают причины ее появления и необходимые условия для развития. В статье обсуждается понятие активной коррозии музейных предметов из железа, медных сплавов и свинца, описываются ее диагностические признаки для каждого металла, предлагаются различные способы ее выявления и тестирования. Особый акцент делается на активной коррозии археологических предметов.

Ключевые слова: археологический металл, музейный предмет, реставрация металла, коррозия металла, активная коррозия, тестирование активной коррозии.

\section{ACTIVE CORROSION OF MUSEUM METAL OBJECTS AND ITS DIAGNOSING}

\section{S. G. Burshneva, O. Yu. Senatorova}

The term "active corrosion" is widely used to characterize the condition of archaeological metal objects, but there is still no clear definition of this concept either in Russian or foreign special literature. The authors of the paper offer their definition of active corrosion of museum metal objects, describe the causes for its occurrence and the necessary conditions for its development. The paper discusses the concept of active corrosion of museum objects made of iron, copper alloys and lead, describes its diagnostic properties and suggests various methods for its detection and testing. An emphasis is made on active corrosion of archaeological objects.

Keywords: archaeological metal, museum object, metal restoration, metal corrosion, active corrosion, active corrosion testing.

В профессиональной среде реставраторов, музейных хранителей, практикующих археологов, как в России, так и за рубежом, в настоящее время широко используется термин «активная коррозия» для характеристики процессов разрушения на памятниках из металла, в первую очередь на археологических предметах. Этот термин прочно вошел в обиход реставраторов, присутствует в реставрационных паспортах, в описании сохранности экспонатов, в информационных музейных системах. Однако как в отечественной, так и в зарубежной литературе отсутствует четкое определение данного понятия. Учитывая тот факт, что для выбора оптимального метода реставрации музейного предмета из металла в первую очередь необходимо определить, подвержен или нет тот или иной памятник активной коррозии, мы пришли к выводу о необходимости дать определение этого понятия, наиболее полно соответствующее современным требованиям к реставрации музейных коллекций. Помимо терминологии, в статье мы предлагаем способ систематизировать и классифицировать различные виды коррозионных разрушений на музейных памятниках из металла, а также даем описание наиболее характерных диагностических признаков активной коррозии. Данное исследование основано на более чем тридцатилетнем опыте работы авторов статьи с археологическими коллекциями Государственного Эрмитажа и других музеев Российской Федерации.

Как было отмечено исследователями среди самых ранних работ по исследованию сохранности музейных предметов, причиной быстрого разрушения памятников из металла являются «активные элементы», специфические для каждого вида материала: это уксусная кислота и ацетаты для свинца (Скотт, 1935, с. 39; Очерки, 1935, с. 117), наличие хлористых соединений в продуктах коррозии железа (Скотт, 1935 , с. 43 ; Очерки, 1935 , с. 21) и «бронзовая болезнь» для археологических предметов из медных сплавов (Скотт, 1935, с. 52; Очерки, 1935, с. 55). В отечественной литературе для характеристики быстрого разрушения металлических предметов под действием коррозии 
также применяются термины «рецидивная коррозия» для медных сплавов (Калиш, 1966, с. 72) и «активное разрушение» для предметов из железа (Шемаханская, 2015, с. 128).

Впервые термин «активная коррозия» встречается у Ю.Р. Эванса: «Для большинства металлов анодные процессы в зависимости от pH могут привести: или а) к активной коррозии с образованием растворимой соли; или б) к образованию твердого окисла, гидроокиси или основной соли, которые будут утолщать первоначальную пленку и возможно приведут к восстановлению слабых мест» (Эванс, 1962, с. 110). Применительно к археологическим предметам этот термин начал широко использоваться с середины 80-х гг. двадцатого века. Дж.М. Кронин в своей монографии «Тһе elements of archaeological conservation» пишет, что на археологических предметах из металла в погребенных условиях может развиваться одна из двух ситуаций: 1) активная коррозия, при которой металлы формируют растворимые продукты коррозии, которые мигрируют в сторону от металла в окружающую среду; 2) пассивация металла, когда металлы формируют твердые нерастворимые продукты коррозии на поверхности артефактов (Cronyn, 1990, 168).

В Заметках Канадского института консервации (Canadian Conservation Institute) также в 2007 году вышла статья «Определение активной коррозии» (Recognizing active corrosion), где употребляется термин «активная коррозия», который в применении к металлическим предметам означает постоянные потери материала от объекта (CCN Notes 9/1).

В 2007 г. М.А. Лопер-Атиа, реставратор Музея музыки в Париже, предложила термин «реактивированная коррозия» («reactivated corrosion») для описания возобновляющейся коррозии на железных археологических предметах (Loeper-Attia, 2007, с. 192). Автор возражает против употребления термина «активная коррозия», объясняя это тем, что любой тип коррозии будет активным по своей сути. Напротив, термин «реактивация» добавляет важную дополнительную информацию об археологической находке, потому что акцентирует внимание на новом факторе, который снова вызывает коррозию. По мнению автора, термин «реактивированная коррозия» более подходит для обозначения самого процесса возобновления коррозии, а термины «стабильный» («stable») / «нестабильный» («unstable») - для обозначения объекта, который подвержен или не подвержен такой коррозии.

По своей сути термин «активная коррозия», применяемый в музейной практике, обозначает только определенную часть коррозионного процесса, проходящего с высокой скоростью и приводящего к сравнительно быстрому разрушению предмета из металла; активная коррозия встречается далеко не на всех металлических предметах. В современном понимании коррозия металла - это разрушение металлов вследствие химического или электрохимического взаимодействия их с внешней средой. Это самопроизвольно протекающий необратимый процесс превращения металлов в химические соединения. Иными словами, коррозия - естественный процесс перехода металла в термодинамически устойчивое состояние, который происходит неизбежно и остановить его полностью практически невозможно.

Различают внутренние и внешние фактоpbl коррозии. Внутренние факторы, такие как многокомпонентность сплава, структура сплава, качество поверхности и характер декоративной обработки предмета, влияют в первую очередь на вид и скорость коррозии. Внешние факторы (наличие кислорода и воды в окружающей среде и присутствие там различных агрессивных веществ) определяют влияние коррозионной среды на протекание процесса коррозии, определяют формы коррозии. В естественных условиях на поверхности металла скапливается влага с растворенными в ней атмосферными газами $\left(\mathrm{O}_{2}, \mathrm{CO}_{2}, \mathrm{SO}_{2}\right.$ и др.) и другими компонентами окружающей среды, образующими в своей совокупности раствор электролита. При контакте металла с раствором электролита возникает коррозионный процесс, в результате которого на поверхности металла формируются продукты коррозии: в виде пленки в условиях атмосферы и в виде корки - при почвенной коррозии.

Для сохранности музейных памятников определяющей является скорость протекания коррозии. По существующей в промышленности десятибалльной шкале коррозионной стойкости металлов (ГОСТ 13819-68) скорость протекания коррозионного процесса 
Таблица 1. Группы коррозионной стойкости металлов

Таблица 1. Группы коррозионной стойкости металлов

\begin{tabular}{|l|c|c|}
\hline \multirow{2}{*}{ ГРУППА СТОЙКОСТИ } & СКОРОСТЬ КОРРОЗИИ & БАЛЛ \\
\hline I. Совершенно стойкие & менее 0,001 & 1 \\
\hline \multirow{2}{*}{ II. Весьма стойкие } & $0,001-0,005$ & 3 \\
\hline \multirow{2}{*}{ III. Стойкие } & $0,005-0,01$ & 4 \\
& $0,01-0,05$ & 5 \\
\hline \multirow{2}{*}{ IV. Пониженно стойкие } & $0,05-0,1$ & 7 \\
\hline \multirow{2}{*}{ V. Малостойкие } & $0,1-0,5$ & 8 \\
\hline VI. Нестойкие & $0,5-1,0$ & 9 \\
\hline
\end{tabular}

оценивают по десятибалльной шкале, исходя из объема разрушенного коррозией металла в год (табл. 1).

Применительно к музейным предметам для характеристики скорости протекания коррозионных процессов, мы предлагаем разделить коррозию на стативную (1-4 балла), метастативную (5-6 баллов) и активную (7-10 баллов).

При стативной коррозии видимых изменений сохранности предмета не происходит в пределах как минимум одной человеческой жизни (около 80-85 лет), такие памятники не нуждаются в какой-либо противокоррозионной обработке. К подобным памятникам могут быть отнесены предметы из медных сплавов c хорошо сформированной «благородной» патиной, алюминиевые предметы, полностью минерализованные археологические предметы, прошедшие процедуры расчистки и структурного укрепления. При метастативной коррозии изменения сохранности происходят медленно, в течение многих лет, подобные памятники нуждаются в периодическом осмотре и проведении профилактических мероприятий превентивного характера. Это, как правило, все железные предметы независимо от наличия на них защитной пленки, предметы из медных сплавов с тонкими окисными пленками, серебряные предметы, частично минерализованные археологические предметы без активной коррозии.

Активная коррозия развивается на предметах, если в окружающей среде и/или в самом предмете присутствует активатор коррозии, провоцирующий быстрое коррозионное разрушение предмета (от нескольких недель до нескольких лет).
Активатор коррозии - это элемент или вещество, вызывающее ускоренную коррозию. При этом активатор может выступать как катализатор или быть активным участником процесса разрушения. Все активаторы коррозии объединяет одно свойство - они образуют с ионами металла нестойкие соединения, которые быстро распадаются в присутствии кислорода и влаги, при этом высвобождается сам активатор коррозии, который снова вступает в химические реакции с ионами металла, поражая новые области и углубляя уже подвергшиеся разрушению. Освободившиеся в процессе распада неустойчивых соединений ионы металла идут на образование рыхлых порошковых продуктов коррозии на поверхности предметов, в порах или трещинах минеральных корок. Эти свежие рыхлые коррозионные образования и служат основными диагностическими признаками активной коррозии. Как и любые коррозионные процессы, активная коррозия протекает только при наличии достаточного количества кислорода в окружающей среде и при повышенном уровне влажности, при этом для разных металлов критический уровень влажности будет различен. Все активаторы коррозии способны взаимодействовать с водой, или растворяясь в ней, или подвергаясь гидролизу.

Таким образом, для возникновения и развития активной коррозии на музейных предметах из металла необходимо, чтобы в обязательном порядке в окружающей среде одновременно присутствовали три фактора: кислород, влага и активатор коррозии. При этом на поверхности предметов или в структуре его коррозионных образований проявляются видимые глазу диагностические признаки, специфические для каждого металла. 


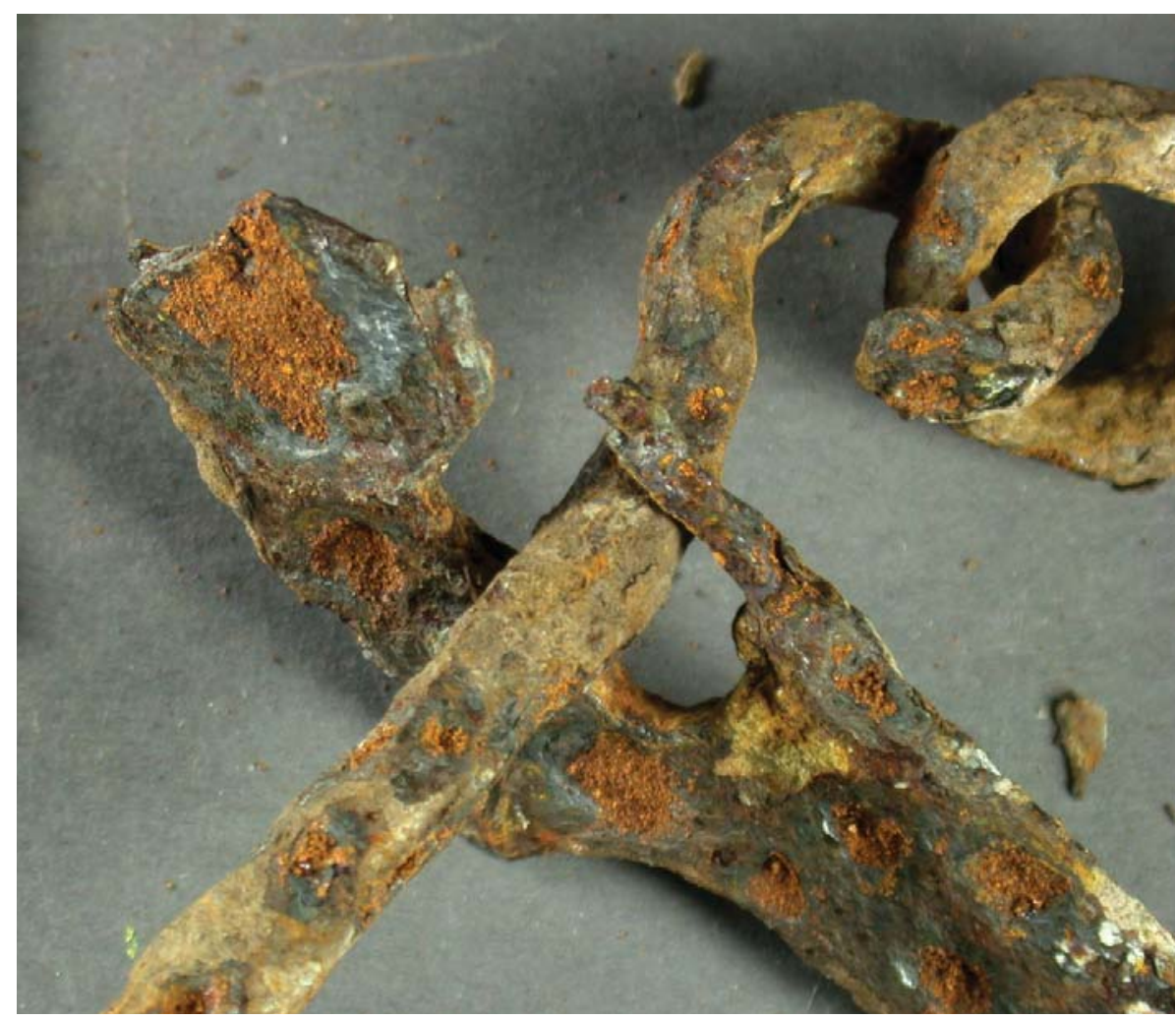

Рис.1. Образование порошкового акаганеита в язвах на поверхности железных псалий в процессе хранения. Фото М.В. Боровиковой.

Fig. 1. Formation of powdery acaganeite in the pits of iron cheekpieces during storage. Photo by M. V. Borovikova.

На основании всего вышесказанного мы можем дать определение активной коррозии музейных предметов из металла. Активная коррозия - постоянно возобновляющийся при достижении критического уровня влажнности и в присутствии активатора коррозии процесс быстрого химического разрушения музейных предметов из металла. При активной коррозии объем поражения может доходить до 10 мм в год, что составляет 7-10 баллов по шкале коррозионной стойкости.

Под действием активной коррозии экспонат из тонкого металла может разрушиться в течение года. На более крупных вещах может оказаться разрушенной оригинальная поверхность, декор, надписи.

Предметы, подверженные стативной коррозии, и предметы, где коррозионный процесс прекратился, в музейной практике принято называть стабильными. Таким образом, одной из основных задач реставратора музейного металла, и в первую очередь реставратора археологического металла, является превращение активного процесса коррозии в неактивный, иными словами - стабилизация активной коррозии на памятнике.
В музейной практике мы чаще всего встречаемся с активной коррозией предметов из железа, меди и ее сплавов, а также свинца. Активная коррозия может присутствовать только на предметах, где сохранилось металлическое ядро.

\section{Активная коррозия железа}

Активную коррозию железа вызывает ион хлора. Содержание свободного хлора или его соединений в окружающей среде довольно высоко. Хлор образует с железом водорастворимые соли, которые растворяются при повышенной влажности, когда на поверхности металла образуется тонкая водяная пленка (от 45\%). Хлориды железа очень гигроскопичны и при повышенной влажности образуют на поверхности предметов влажные капли, окрашенные в желтый или коричневый цвет. Это является диагностическим признаком активной коррозии.

На археологических предметах ион хлора, как правило, присутствует в составе минеральных корок в виде тех же водорастворимых хлоридов железа или в составе оксигидратов железа, в частности рыже-бурого минерала акаганеита, обязательным условием формирования которого является присут- 


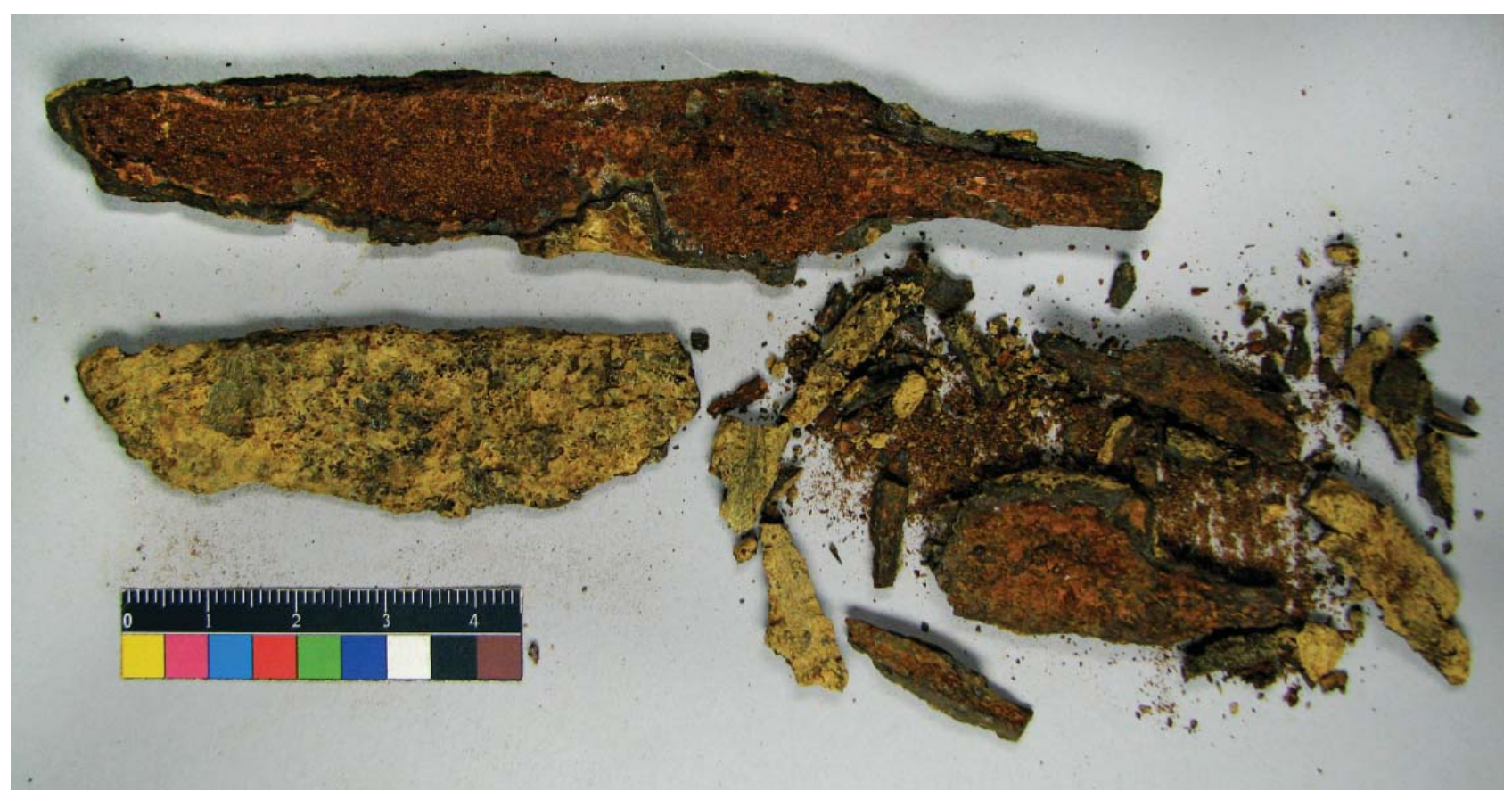

Рис .2. Образование порошкового акаганеита на металлическом ядре железного ножа через год после раскопок. Фото С.Г. Буршневой.

Fig. 2. Formation of powdery acaganeite on the metal core of an iron knife a year after excavation. Photo by S. G. Burshneva.

ствие ионов хлора. Именно образование порошкового акаганеита является диагностическим признаком активной коррозии археологических предметов из железа. Акаганеит чаще всего образуется в неглубоких язвах на поверхности предметов (рис. 1) или покрывает металлическое ядро, обнажившееся вследствие утраты минеральной корки (рис. 2).

На археологических памятниках ион хлора активизируется при относительной влажности от 18\% (Knight, 1997, p. 38). Исключение составляют предметы, найденные в море. Для них коррозионный процесс возобновляется уже при 10\% RH (North, 1982, p. 81). Кислород для железа служит катализатором коррозии, его присутствие для развития процесса активной коррозии обязательно наравне с влагой.

\section{Активная коррозия меди и сплавов}

Так же, как и на железных предметах, активную коррозию медных сплавов вызывает ион хлора. На предметах из металла ион хлора также может образовывать водорастворимые соли хлорида меди (I) $\mathrm{CuCl}_{2}$ яркозеленого цвета. Растворимые хлориды меди не так гигроскопичны, как у железа, поэтому для диагностирования активной коррозии на неархеологических предметах из меди и сплавов необходимо применять дополнительные методы тестирования, в частности капельный анализ (аргентометрию).

На археологических предметах хлор способен образовывать два соединения: водорастворимый хлорид меди (I) $\mathrm{CuCl}_{2}$ и нерастворимый в воде, но неустойчивый во влажном воздухе хлорид меди (II) $\mathrm{CuCl}$ - минерал нантокит, минерал белого, переходящего в серый цвета, слегка вязкий на ощупь, который осаживается на поверхности металла под минеральными корками. В присутствии кислорода и влаги нантокит преобразуется в основные хлориды меди атакамит или паратакамит - ярко-зеленый рыхлый порошок, который и служит диагностическим признаком активной коррозии на археологических предметах из медных сплавов. Как правило, эти продукты коррозии образуют рыхлые «бородавки» на поверхности предметов (рис. 3) или заполняют небольшие язвы (рис. 4). Сами по себе основные хлориды меди устойчивы, не реагируют ни с кислородом, ни с влагой. Однако, имея рыхлую структуру, они полностью проницаемы для молекул воды и кислорода и, соответственно, не способны создать защитного барьера, поэтому процесс разложения нантокита будет идти до конца. Образуясь на поверхности металлического ядра и имея 


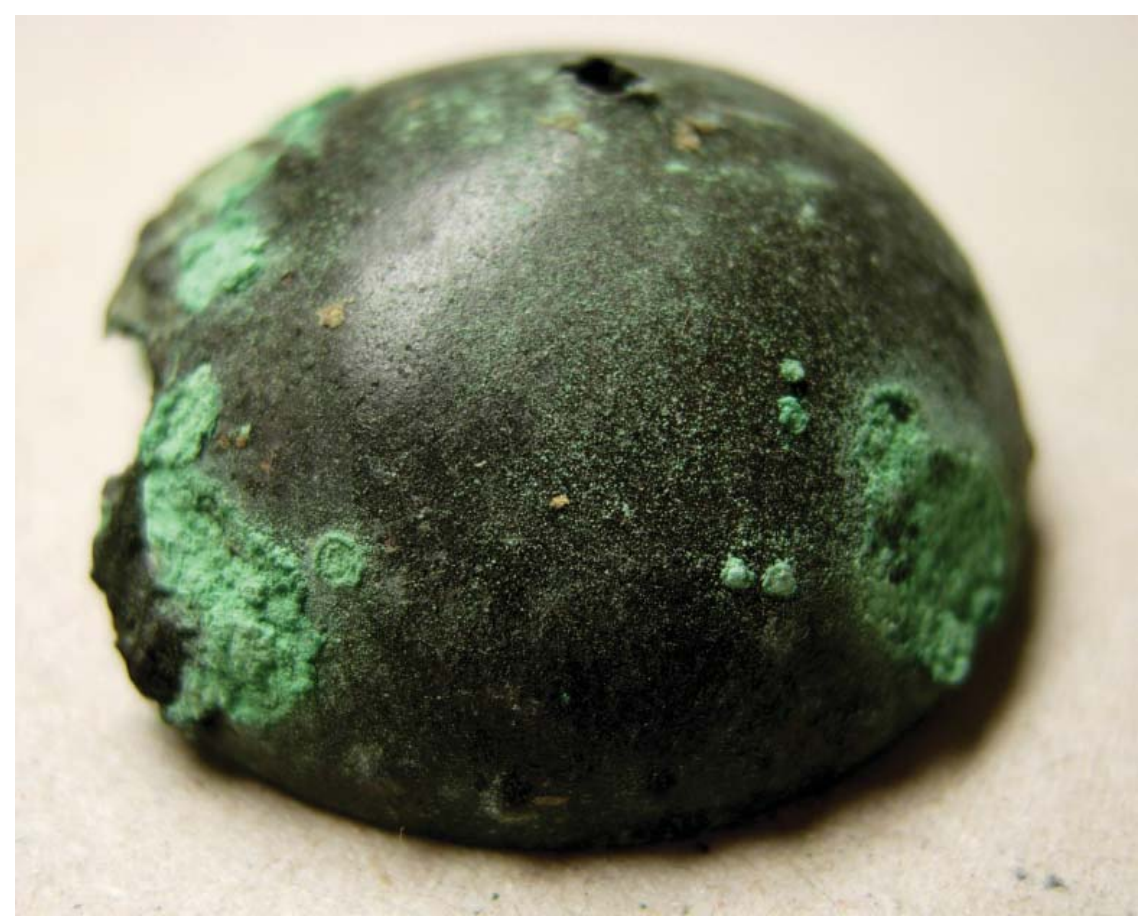

Рис. 3. Развитие пустул активной коррозии на поверхности бронзовых предметов из Южной Сибири. Фото С.Г. Буршневой.

Fig. 3. Development of active corrosion pustules on the surface of bronze objects from South Siberia. Photo by S. G. Burshneva.

рыхлую структуру, основные хлориды меди занимают больший объем в пространстве, чем нантокит, и способны разорвать предмет. Процесс перехода нантокита в основные хлориды меди при повышенной влажности происходит очень быстро, поэтому для тестирования активной коррозии на археологических предметах из меди и сплавов достаточно поместить их во влажную камеру на одни сутки.

Влажность, при которой хлориды меди остаются стабильными, не должна превышать 45\% (Шемаханская, 2015, с. 122).

\section{Активная коррозия свинца}

Активаторами коррозии для свинцовых предметов, как «нового» металла, так и археологических, служат пары органических кислот, прежде всего уксусной и муравьиной, дающие водорастворимые ацетаты и формиаты свинца, а также углекислый газ. При этом органические кислоты реагируют не только с металлическим свинцом, но также способны растворять защитные пленки оксидов и карбоната свинца, также формируя водорастворимые соли свинца. В присутствии углекислого газа, кислорода и влаги ацетаты свинца довольно быстро переходят в белый карбонат свинца в виде рыхлых порошковых образований на поверхности и в трещинах предметов (рис. 5). Часто эти белые порошковые образования можно рассмотреть только с лупой или под микроскопом (рис. 6). При этом снова высвобождается уксусная кислота, способная вступать в реакцию со свинцом и его соединениями. Реакция будет идти по кругу, пока из нее не будут полностью удалены все следы уксусной кислоты. Образующиеся в ходе реакции порошковый белый карбонат свинца не выполняет никаких защитных функций и служит диагностическим признаком активной коррозии свинца.

Углекислый газ выступает не только как катализатор активной коррозии свинца. Углекислый газ способен растворяться в воде с образованием раствора угольной кислоты. При повышенной влажности, когда на предметах из свинца образуется тончайшая пленка влаги, образовавшийся в присутствии углекислого газа раствор угольной кислоты будет растворять защитные карбонатные пленки и реагировать с металлическим свинцом, образуя те же рыхлые порошковые образования белого карбоната свинца на поверхности предметов.

Таким образом, о начале активного процесса свидетельствует наличие очагов активной коррозии: 


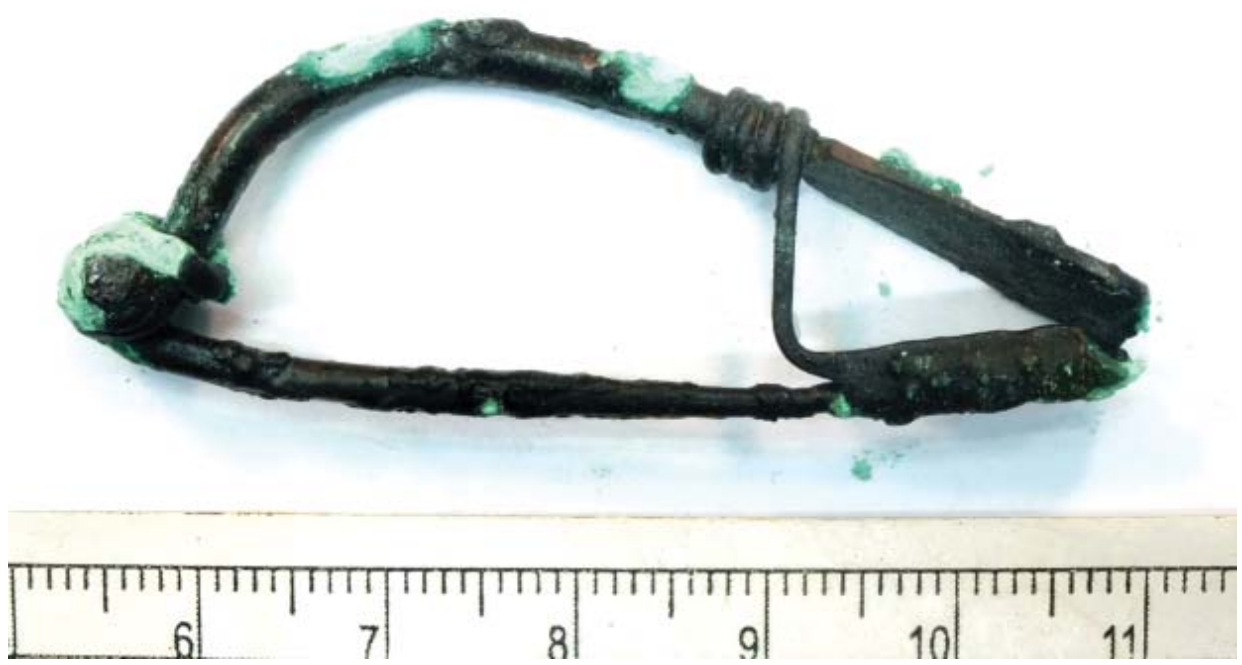

Рис. 4. Язвы активной коррозии на поверхности бронзовой фибулы. Фото Р.В. Котова.

Fig. 4. Active corrosion pits on the surface of a bronze brooch. Photo by R. V. Kotov.

- $\quad$ На предметах из медных сплавов - это язвенные или точечные поражения, заполненные сыпучими продуктами коррозии яркозеленого цвета.

- На предметах из железа - это неглубокие язвы, заполненные сыпучими продуктами коррозии рыже-бурого цвета, или обнажившееся металлическое ядро, покрытое также сыпучими продуктами коррозии рыже-бурого цвета.

- На предметах из свинца - это порошковые образования белого цвета. Они могут располагаться на поверхности, находиться в трещинах металла или минеральной корки, образовывать язвы.

Наибольшего внимания требуют предметы из так называемой «группы риска»: археологические предметы из железа и бронзы с сохранившимся металлическим ядром, найденные на территориях, где в составе почв содержится большое количество хлора; археологические предметы из свинца с нарушенной минеральной коркой.

Обнаруженные визуально или с помощью оптических приборов признаки активной коррозии позволяют нам предположить ее наличие. Для подтверждения наличия активной коррозии необходимо:

наблюдать за динамикой процесса в течение некоторого времени. Наиболее ярко динамика проявляется при смене отопительных сезонов, когда происходят наиболее значительные и резкие скачки влажности; для железных и бронзовых предметов использовать методы тестирования.

Тестирование предметов, находящихся в группе риска, можно проводить в процессе обследования памятника и составления реставрационного задания, даже если на поверхности нет признаков активной коррозии. В процессе реставрационной обработки памятника тестирование активной коррозии является обязательной процедурой. Существует несколько методов тестирования активной коррозии. Все они применимы только для предметов из железа и медных сплавов, так как предназначены для выявления хлора в составе продуктов коррозии. Для свинцовых предметов внешние диагностические признаки остаются основным методом выявления активной коррозии.

Тестирование активной коррозии во влажной камере

Влажная камера - герметично закрывающаяся емкость, где искусственно поддерживается относительная влажность 90-100\%. Чаще всего влажная камера делается из эксикатора с притертой крышкой. В полевых условиях ее можно сделать из любого герметично закрывающегося контейнера, в который можно поместить пластиковую полочку с отверстиями. На дно контейнера наливается вода, предмет кладется на керамический диск с отверстиями или пластиковую полочку с отверстиями. Повышенная влажность в камере провоцирует быстрое развитие активной коррозии. 


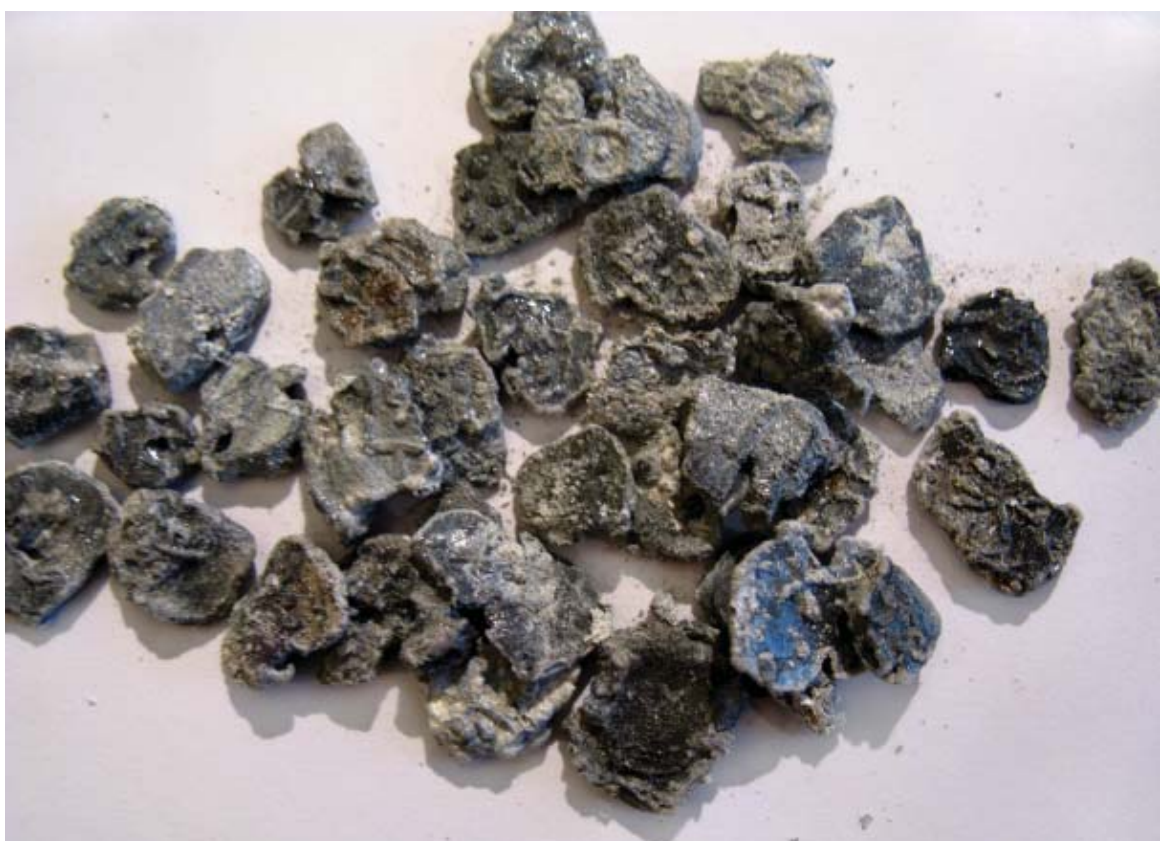

Рис. 5. Свинцовые пломбы с признаками активной коррозии. Фото О.Ю. Сенаторовой. Fig. 5. Lead seals with active corrosion marks. Photo by O. Yu. Senatorova.

Предметы помещаются во влажную камеру на срок от нескольких часов до трех суток - в зависимости от толщины и плотности коррозионного слоя. В случае наличия активной коррозии на поверхности предмета появляются окрашенные солями металла капли влаги или новые порошкообразные образования: для железа - желтого или светло-коричневого цвета, для меди - зеленого цвета. Не рекомендуется выдерживание предмета во влажной камере более трех суток, так как создаются условия для развития коррозионного процесса на здоровой поверхности.

Проверка во влажной камере необходима как для выявления активной коррозии до начала реставрации, так и после стабилизации предмета. В случае, если проверка во влажной камере показала наличие активной коррозии, необходимо проводить стабилизацию до полной остановки активного процесса.

Тестирование путем определения иона хлора в водных растворах

Наличие иона хлора (активатора коррозии для железа и медных сплавов) можно определить, экстрагировав его в водный раствор. Сделать это можно двумя способами. Первый - применение nульпьы. Для этого компресс из фильтровальной бумаги накладывается на предполагаемый очаг активной коррозии и смачивается дистиллированной водой. При высыхании соли мигрируют в компресс. После полного высыхания компресс и накопившиеся в нём соли снимаются. Затем компресс помещают в мензурку с дистиллированной водой и выдерживается некоторое время. Этот способ можно применять для тестирования перед реставрацией. Второй способ экстракции хлоридов применяется в процессе реставрационной обработки. По сути, это определение наличия иона хлора в промывочной воде, из которой был извлечен предмет после очередного этапа стабилизации путем промывки. Измерение должно проводиться на всех этапах стабилизации с целью отслеживания динамики процесса до полного исчезновения хлора из воды. Следует помнить, что для правильного определения динамики процесса необходимо, чтобы объем воды, в которой находится предмет, был одинаковым на всех этапах стабилизации.

Определение наличия ионов хлора в воде или водном растворе может быть проведено несколькими способами.

Измерение можно проводить с помощью индикатора концентрации активного хлора. Для этого в мензурку или стакан наливают 50-100 мл воды, в которой надо определить содержание хлоридов (промывочная вода или дистиллированная с пульпой). Из пенала достают индикаторную полоску и погружают ее на 1-2 сек. в раствор так, чтобы была смочена индикаторная зона. Далее полоску извлека- 


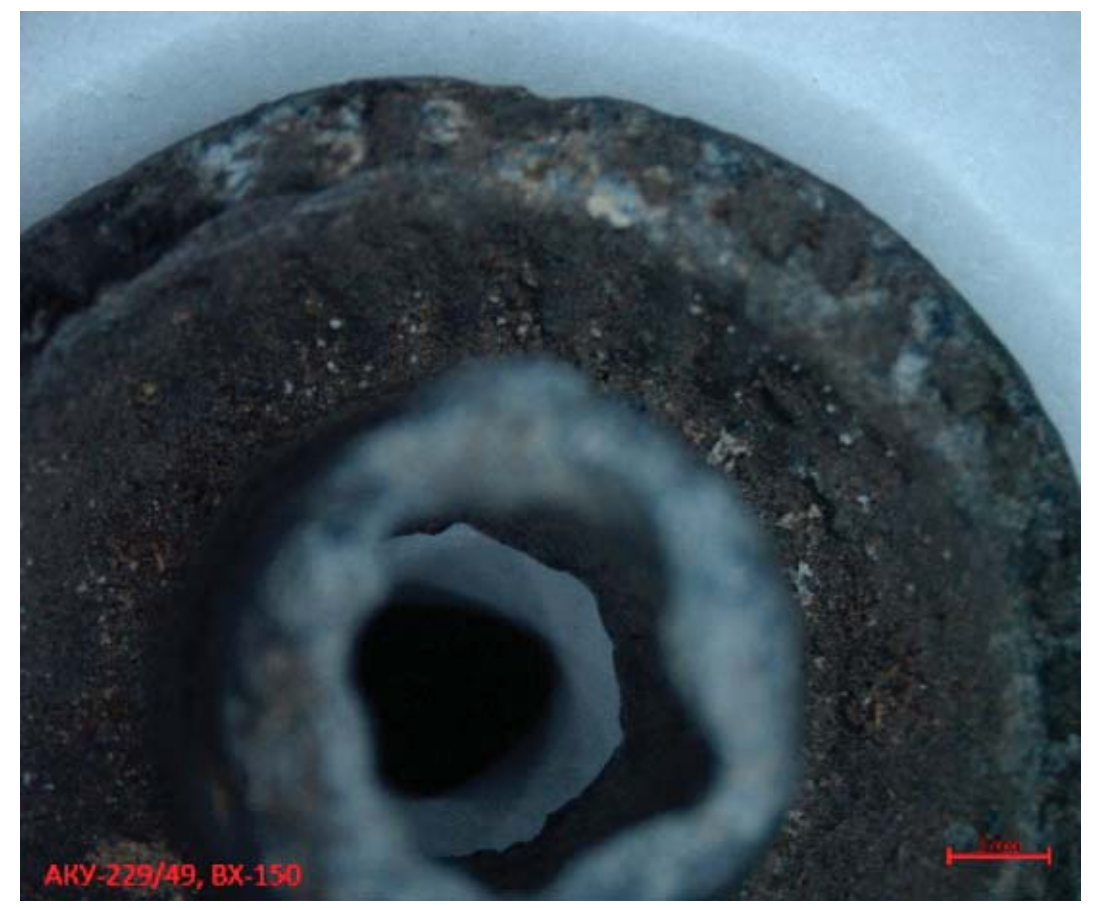

Рис.6. Признаки активной коррозии на поверхности свинцовой пломбы. Макросъемка, микроскоп Zeizz Stemi 305 ув. 10х3. Фото А.Р. Нуретдиновой.

Fig. 6. Active corrosion marks on the surface of a lead seal.

Macro photography, microscope - Zeizz Stemi 305 uv. 10x3. Photo by A. R. Nuretdinova.

ют из раствора и быстро (в течение 1-2 сек.) удаляют избыток жидкости, проводя ребром полоски о край стакана. Полоску кладут на белую фильтровальную бумагу или бумажную салфетку индикаторной зоной вверх и выдерживают 10 сек., после чего в течение не более 5-10 сек. сопоставляют цвет индикаторной зоны с цветовой шкалой элемента сравнения, определяя концентрацию рабочего раствора. Очень важно правильно соблюдать указанное время выдержки индикаторных полосок в растворе и на фильтрованной бумаге и не подвергать элемент сравнения воздействию прямого солнечного света и дезинфицирующих средств. Определение концентраций рабочего раствора рекомендуется проводить 3 раза. Результат определения считается достоверным, если он оказался одинаковым не менее чем в двух повторных определениях.

В лаборатории Государственного управления по охране памятников и Археологическом музее земли Бранденбург (Brandenburgisches Landesamt für Denkmalpflege und Archäologisches Landesmuseum), Германия, применяется меркуриметрический метод определения количества хлоридов в водном растворе. Метод основан на том, что ионы хлора титруются раствором нитрата ртути (II), в качестве индикатора используется колориметрический реагент - раствор 1,5-дифенилкарбазона. Готовые тест-системы особенно удобны тем, что все реагенты уже приготовлены и поставляются во флаконах с дозирующими пипетками. Кроме того, они наглядны и достаточно точны - показывают концентрацию хлоридов до 10 мг/л. Метод используется в готовых тест-системах различных производителей (например, MQuant Chloride Test компании Merck).

Измерение можно проводить с помощью хлориметра. Хлориметры производят промышленным способом для измерения содержания хлора в воде и водных растворах. Принцип, положенный в основу измерений содержания хлора в воде, основывается на принципе DPD (Dissipative Particle Dynamics) - динамическом рассеивании частиц. Существуют различные марки хлориметров. Измерение следует проводить по инструкции, приложенной к хлориметру.

Качественный анализ на хлориды с помощью нитрата серебра (азотнокислого серебра) получил название аргентометрия. Методика определения анионов хлора $\left(\mathrm{Cl}^{-}\right)$в продуктах коррозии, на пористых материалах, а также в воде следующая: 
Отобрать пробу, измельчить, поместить на предметное стекло или в пробирку;

Добавить несколько капель дистиллированной воды;

Добавить две капли раствора азотной кислоты (для приготовления раствора (1:1) добавить концентрированную азотную кислоту $\left(\mathrm{HNO}_{3}\right)$ к равному количеству дистиллированной воды);

Добавить каплю раствора азотнокислого серебра (для приготовления раствора $0.2 \mathrm{M}$ растворить 1,5 г $\mathrm{AgNO}_{3}$ в 50 мл дистиллированной воды. Раствор необходимо хранить в темной ёмкости); результаты анализа будут видны более отчетливо на темном фоне (Odegaard et al., 2000, p. 108-109).

В кислой среде хлорид-ион с азотнокислым серебром образует белый творожистый осадок. По величине осадка можно судить о количественном содержании хлоридов в исследуемом веществе: чем больше осадок, тем больше хлоридов. Реакция очень чувствительная, помутнения наблюдаются даже при незначительных концентрациях хлоридов (табл. 2).
Аналогичным способом можно определить наличие иона хлора в промывочной воде.

Наиболее надежным способом тестирования активной коррозии на музейных предметах из железа и медных сплавов является помещение их во влажную камеру, потому что при этом провоцируется быстрая активация коррозионных процессов. Однако же применение этого способа ограничено. Его можно применять только в том случае, если состояние сохранности предмета позволяет применить последующую обработку методом интенсивной горячей промывки и другие активные способы стабилизации, а также если на предмете отсутствуют детали из органических материалов или другие металлы. Тестирование промывочной воды основано на предварительной экстракции хлоридов из коррозионных структур, что может и не произойти в процессе промывки или накладывания пульпы, если поры заблокированы нерастворимыми продуктами коррозии или кислородом. Экспериментально было доказано, что после обработки железных археологических предметов с активной коррозией

\begin{tabular}{|c|c|}
\hline Характеристика осадка или мути & Содержание $\mathrm{Cl}$, г/л \\
\hline 1. Опалесценция или слабая муть & $0,001 \div 0,01$ \\
\hline 2. Сильная муть & $0,01 \div 0,05$ \\
\hline 3. Образуются хлопья, осаждаются не сразу & $0,05 \div 0,1$ \\
\hline 4. Белый объемный осадок & Более 0,1 \\
\hline
\end{tabular}

в растворе щелочного сульфита и последующей промывки хлорид-анионов в промывочной воде зафиксировано не было, но тестирование во влажной камере тем не менее показало наличие активной коррозии (Буршнева и др., 2012, с. 139-146). В ряде случаев единственно возможным способом выявления активатора коррозии может быть только накладывание пульпы. Тестирование промывочной воды проводится обычно в процесce стабилизации. На завершающем этапе необходимо провести исследование во влажной камере.
После визуального обследования и выявления диагностических признаков активной коррозии можно подтвердить правильность сделанных выводов, установив минералогический состав порошковых коррозионных образований с помощью аналитического оборудования.

Для достижения объективности обследование памятника должно быть комплексным. Диагностические признаки активной коррозии выявляются визуально и с помощью оптической микроскопии, а наличие активатора коррозии подтверждается тестированием.

\section{ЛИТЕРАТУРА}

Буршнева С.Г., Кузнецова О.Б., Смирнова Н.В. Исследование и тестирование метода стабилизации железных археологических предметов с применением ультразвука // Проблемы реставрации памятников культуры и искусства. Материалы III региональной науч.-практической конф., посвященной 15-летию Эрмитажной школы реставрации. Екатеринбург: Тезис, 2012. С. 139-146.

Калиш М.К. Естественные защитные плёнки на медных сплавах. М.: Металлургия, 1971. 200с. 
Очерки по методике технологического исследования, реставрации и консервации древних металлических изделий / ИГАИМК. Вып. 130. М.-Л.: ОГИЗ, 1935. 121 с.

Скотт A. Очистка и реставрация музейных экспонатов. Пер. с англ. В.А. Фроловой и В.Е. Фармаковской / ИГАИМК. Вып. 114. М.-Л.: ОГИЗ, 1935. 72 с.

Шемаханская М.С., Металлы и вещи: история, свойства, разрушение, реставрация. М.: Индрик, 2015. 288 с.

Эванс Ю.Р., Коррозия и окисление металлов (теоретические основы и их практическое приложение). Пер. с англ. под ред. д-ра хим. Наук проф. И.Л. Розенфельда. М.: Гос. Науч.-тех. Изд-во машиностроительной лит-ры, $1962 ., 857 \mathrm{c}$.

Cronyn J.M. The Elements of Archaeological Conservation. London: Routledge, 1990. 326 p.

Knight B., The Stabilization of Archaeological Iron. Past, Present and Future // Metal 95: Proceedings of the International Conference on Metals Conservation. London: James \& James (Science Publisher) Ltd, 1997. P. 36-40.

Recognizing Active Corrosion, Canadian Conservation Institute (CCI) Notes 9/1, 2007, https://www. canada.ca/en/conservation-institute/services/conservation-preservation-publications/canadian-conservationinstitute-notes/recognizing-active-corrosion.html, 9/08/2020

North N.A., Corrosion Products on Marine Iron // Studies in Conservation 27, 1982. P. 75-83.

Odegaard, N., Carroll, S. and Zimmt, W. S. Material Characterization Tests for Objects of Art and Archaeology. London: Archetype Publications Ltd, 2000. 242 p.

Loeper-Attia M.A., A Proposal to Describe Reactivated Corrosion of Archaeological Iron Objects / Corrosion of Metallic Heritage Artefacts. Investigation, Conservation and Prediction of Long Term Behaviour. European Federation of Corrosion (EFC) Series, 2007. P. 190-202.

\section{Информация об авторах:}

Буршнева Светлана Георгиевна, художник-реставратор высшей категории, Отдел научной реставрации и консервации Государственного Эрмитажа (г. Санкт-Петербург, Россия); младший научный сотрудник Музея археологии Института археологии им. А.Х. Халикова (г.Казань, Россия); burshneva@yandex.ru

Сенаторова Ольга Юрьевна, художник-реставратор высшей категории, Отдел научной реставрации и консервации Государственного Эрмитажа (г. Санкт-Петербург, Россия) o.y.senatorova@yandex.ru

\section{REFERENCES}

Burshneva, S. G., Kuznetsova, O. B., Smirnova, N. B. 2012. In Problemy restavratsii pamiatnikov kul'tury i iskusstva (Issues of Restoration of Culture and Art Monuments). Yekaterinburg: "Tezis" Publ., 139-146

Kalish, M. K. 1971. Estestvennye zashchitnye pleonki na mednykh splavakh (Natural Protective Films on Copper Alloys). Moscow: "Metallurgiia" Publ. (in Russian).

1935. Ocherki po metodike tekhnologicheskogo issledovaniia, restavratsii $i$ konservatsii drevnih metallicheskih izdelii (Essays on the Methodology of Technological Research, Restoration and Conservation of Ancient Metal Objects). Series: Izvestiia Gosudarstvennoi Akademii istorii material'noi kul'tury (Bulletin of the State Academy for the History of Material Culture). Vol. 130. Leningrad: "OGIZ" Publ. (in Russian).

Skott, A. 1935. Ochistka i restavratsiia muzenykh eksponatov (Cleaning and Restoration of Museum Exhibits). Series: Izvestiia Gosudarstvennoi Akademii istorii material'noi kul'tury (Bulletin of the State Academy for the History of Material Culture). Vol. 114. Leningrad: "OGIZ” Publ. (in Russian).

Shemakhanskaia, M. S. 2015. Metally i veshchi: istoriia, svoistva, razrushenie, restavratsiia (Metals and Objects: History, Properties, Destruction, Restoration). Moscow: "Indrik" Publ. (in Russian).

Evans, Yu. P. 1962. Korroziia i okislenie metallov (teoreticheskie osnovy i ikh prakticheskoe prilozhenie) (Corrosion and Oxidation of Metals (Theoretical Foundations and Practical Application). Moscow (in Russian).

Cronyn J. M. 1990. The Elements of Archaeological Conservation. London: Routledge.

Knight, B. 1997. In Metal 95: Proceedings of the International Conference on Metals Conservation. London: James \& James (Science Publisher) Ltd, 36-40.

Recognizing Active Corrosion, Canadian Conservation Institute (CCI) Notes 9/1, 2007, https://www. canada.ca/en/conservation-institute/services/conservation-preservation-publications/canadian-conservationinstitute-notes/recognizing-active-corrosion.html, 9/08/2020

North N. A. 1982. In Studies in Conservation 27, 75-83.

Odegaard, N., Carroll, S. and Zimmt, W. S. 2000. Material Characterization Tests for Objects of Art and Archaeology. London: Archetype Publications Ltd. 
Loeper-Attia, M. A. 2007. In Corrosion of Metallic Heritage Artefacts. Investigation, Conservation and Prediction of Long Term Behaviour. European Federation of Corrosion (EFC) Series, 190-202.

About the Authors:

Burshneva Svetlana G. Conservator of highest qualification, State Hermitage. Dvortsovaya Naberezhnaya (Embankment), 34, Saint Petersburg, 190 000, Russian Federation; Institute of Archaeology named after A. Kh. Khalikov, Tatarstan Academy of Sciences. Butlerov Str., 30, Kazan, 420012, the Republic of Tatarstan, Russian Federation; burshneva@yandex.ru

Senatorova Olga Yu. metal conservator of highest qualification, State Hermitage. Dvortsovaya Naberezhnaya (Embankment), 34, Saint Petersburg, 190 000, Russian Federation; o.y.senatorova@yandex.ru

Статья поступила в журнал 01.10.2021 г. Статья принята к публикации 01.12.2021 г. Авторы внесли равноценный вклад в работу. 